\title{
Environmental factors modulating the abundance and distribution of Callinectes danae (Decapoda: Portunidae) from two areas of the southeastern coast of Brazil
}

\author{
Bárbara A. Martins ${ }^{1}$, Rafaela T. Pereira ${ }^{1}$, Vivian Fransozo ${ }^{2}$, Gustavo M. Teixeira ${ }^{3}$, \\ Michele Furlan ${ }^{1}$ \& Adilson Fransozo ${ }^{1}$ \\ ${ }^{1}$ NEBECC (Crustacean Biology, Ecology and Culture Study Group), Departamento de Zoologia, Instituto de Biociencias, \\ Universidade Estadual Paulista Júlio de Mesquita Filho - Campus de Botucatu, 18618-970 Botucatu, São Paulo, Brasil; \\ e-mail: barbara.a.martins@hotmail.com \\ ${ }^{2}$ Universidade Estadual do Sudoeste da Bahia - Campus de Vitória da Conquista, 45031-900, Vitória da Conquista, Bahia, \\ Brasil \\ ${ }^{3}$ Departamento de Biologia Animal e Vegetal da Universidade Estadual de Londrina, 86051-990, Londrina, Paraná, Brasil
}

\begin{abstract}
The distribution and abundance of marine organisms are directly or indirectly a function of biotic and abiotic features such as sediment and water properties. In this study we analyzed the spatial and temporal distribution of Callinectes danae in two distinct littoral areas of the northern coast of the State of São Paulo, Brazil and associated them with local geomorphologic features and environmental factors. We collected specimens on a monthly basis, from July 2001 to June 2003, using a fishing boat equipped with double-rig net, in two locations: Ubatuba (UBA) and Caraguatatuba (CAR). Collecting was carried out in seven transects with different depths, which were further subdivided into two regions: bay region (5, 10, 15 and $20 \mathrm{~m}$ deep); and inner shelf region (25, 30 and $35 \mathrm{~m}$ deep). Samples from different periods and transects differed significantly in abundance. A positive correlation was found between the abundance of $C$. danae and the following parameters: temperature at the bottom, organic matter content and Phi (grain diameter). By contrast, a negative correlation was established between specimen abundance and salinity at the bottom. The total abundance was highest in 5 $\mathrm{m}$ deep transects in both regions. Summer was the season when individuals were least abundant in both areas. We concluded that the spatial and temporal distribution of $C$. danae are determined by a set of environmental factors and not just by one single factor.
\end{abstract}

Key words: Brachyura; salinity; spatial and seasonal distribution; temperature

\section{Introduction}

The abundance and distribution of marine organisms are usually modulated by environmental factors. These can act singly or in combination, expanding or reducing the area occupied by a given species (Vernberg \& Vernberg 1970; Pinheiro et al. 1996; Mantelatto et al. 1995; Fantucci et al. 2009). Salinity, temperature, sediment texture and organic matter content are the principal environmental factors implicated in the distribution of decapod crustaceans (Santos et al. 1994; Pinheiro et al. 1996; Atrill et al. 1999; Bertini et al. 2001; Martinez et al. 2009; Carvalho et al. 2010; Carvalho \& Couto 2010). Additionally, some authors have suggested that variations in the benthic marine composition are closely linked to the depth gradient (Aschan 1990; Bertini \& Fransozo 2004; Fransozo et al. 2007; Hiroki et al. 2011). Given that the interaction among factors generates different patterns of spatial and seasonal distribution, research aimed to comprehend the biology of marine crustaceans should include various environmental determinants and depth gradients (Buchanan \& Stoner 1988).
The swimming crab Callinectes danae (Smith, 1869 ) is widely distributed in the East Coast of the Americas, ranging from Florida (USA) to Rio Grande do Sul (Brazil) and can be found in estuarine areas and mangroves up to depths of $70 \mathrm{~m}$ (Melo 1996). The species is a fishing resource in many regions of Brazil (Branco \& Masunari 1992; Barreto et al. 2006; Pereira et al. 2009) and it is also found in Xiphopenaeus kroyeri Heller, 1862 fishing by-catch (Baptista-Metri et al. 2005).

The biology of $C$. danae in the Brazilian coast has been addressed in the following studies: Pita et al. (1985) studied the distribution and size of individuals at first maturation; Branco (1996) and Branco \& Verani (1997) examined the feeding dynamics; Medeiros \& Oshiro (1990) and Costa \& Negreiros-Fransozo (1998) analyzed population and reproductive biology; Chacur \& Negreiros-Fransozo (2001) investigated the spatial and seasonal distributions; Baptista-Metri et al. (2005) analyzed the population biology and reproduction by looking at by-catch of Xiphopenaeus kroyeri tailing fishing; and Keunecke et al. (2008) studied the growth of spec- 


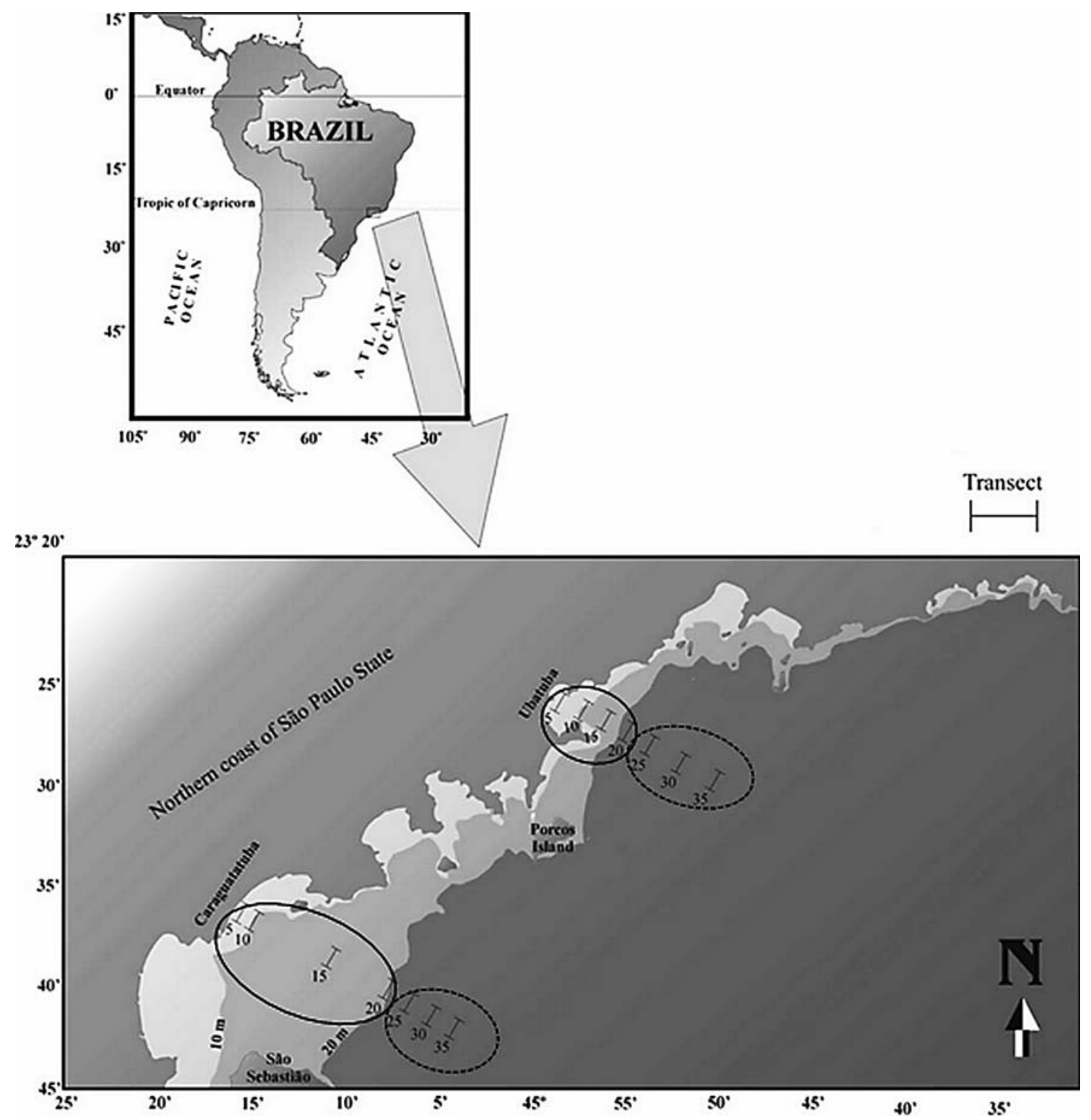

Fig. 1. Study area: location of Ubatuba and Caraguatatuba, indicating the sampling sites of transects. Transects 5 , 10,15 and $20 \mathrm{~m}$ were considered as shallow water area and 25,30 and $35 \mathrm{~m}$ as inner shelf area.

imens collected during shrimp fishing. Strong habitat partitioning was found for $C$. danae: while males and juveniles are collected mostly at the inner estuary, adult females are found in the entire bay, and ovigerous females occur almost exclusively at deeper layers where salinity is higher (Sforza et al. 2010).

In this study we compared the spatial-temporal distribution of $C$. danae in two different areas of the southeastern Brazilian coast and endeavoured to find associations between distributional patterns and environmental factors.

\section{Material and methods}

Individuals were collected monthly from July 2001 to June 2003, from two areas (Ubatuba: UBA $23^{\circ} 26^{\prime} 27^{\prime \prime} \mathrm{S}$ - $45^{\circ} 03^{\prime} 18^{\prime \prime} \mathrm{W}$; Caraguatatuba: CAR $23^{\circ} 36^{\prime} 09^{\prime \prime} \mathrm{S}$ $\left.45^{\circ} 20^{\prime} 25^{\prime \prime} \mathrm{W}\right)$ on the northern coast of São Paulo, Southeastern Brazil. Seven transects were sampled in each area, at $5,10,15$ and $20 \mathrm{~m}$, herein called bay region, and 25, 30 and $35 \mathrm{~m}$ deep, referred to as inner shelf region (Fig. 1). We used a GPS (Global Positioning System) to delimitate the beginning and the end of each transect, and recorded the depths with an ecobathymeter attached to a GPS. A shrimp boat equipped with a double-rig net $(20 \mathrm{~mm}$ mesh size and $15 \mathrm{~mm}$ in the cod end) was used for to trawling, which lasted $30 \mathrm{~min}$ in each transect, sampling a total area of $18,000 \mathrm{~m}^{2}$.

We used a Nansen bottle to sample the bottom and surface water at the beginning, middle and end of each transect. We also measured salinity (psu), with the aid of an Atago $\mathrm{S} / 1000$ optical refractometer, and temperature $\left({ }^{\circ} \mathrm{C}\right)$ with a mercury thermometer. In analyses, we input the average of these three values. Sediment samples were collected in each season with a 0.06 mň Van Veen Grab Sampler. In the laboratory, the sediment was dried at $70^{\circ} \mathrm{C}$ for $72 \mathrm{~h}$ in an oven. For the analysis of grain size composition, two $50 \mathrm{~g}$ sub-samples were separated, treated with $250 \mathrm{ml}$ of a $0.2 \mathrm{~N}$ $\mathrm{NaOH}$ solution, and stirred for $5 \mathrm{~min}$ to release the silt and clay particles. Subsamples were then rinsed on a 0.063 sieve.

Sediments were sieved through $2 \mathrm{~mm}$ (gravel); 2.0- 
Table 1. Monthly collections of Callinectes danae in each area $\left(1^{\text {st }}\right.$ period $=$ July 2001 to June $2002 ; 2^{\text {nd }}$ period $=$ July 2002 to June 2003), and total for each season.

\begin{tabular}{|c|c|c|c|c|c|c|c|c|}
\hline \multirow{2}{*}{ Month } & \multicolumn{2}{|c|}{ UBA } & \multirow{2}{*}{ Total } & \multirow{2}{*}{ UBA seasons } & \multicolumn{2}{|c|}{$\mathrm{CA}$} & \multirow{2}{*}{ Total } & \multirow{2}{*}{ CA seasons } \\
\hline & $1^{\text {st }}$ & $2^{\text {nd }}$ & & & $1^{\text {st }}$ & $2^{\text {nd }}$ & & \\
\hline July & 19 & 1 & 20 & \multirow{3}{*}{ Winter $=151$} & 31 & 3 & 34 & \multirow{3}{*}{ Winter $=67$} \\
\hline Aug. & 61 & 5 & 66 & & 20 & 0 & 20 & \\
\hline Sept. & 58 & 7 & 65 & & 11 & 2 & 13 & \\
\hline Oct. & 25 & 11 & 36 & \multirow{3}{*}{ Spring $=123$} & 13 & 5 & 18 & \multirow{3}{*}{ Spring $=31$} \\
\hline Nov. & 19 & 29 & 48 & & 4 & 2 & 6 & \\
\hline Dec. & 30 & 9 & 39 & & 4 & 3 & 7 & \\
\hline Jan. & 17 & 13 & 30 & \multirow{3}{*}{ Summer $=117$} & 6 & 2 & 8 & \multirow{3}{*}{ Summer $=19$} \\
\hline Febr. & 46 & 5 & 51 & & 6 & 1 & 7 & \\
\hline Mar. & 36 & 0 & 36 & & 2 & 2 & 4 & \\
\hline Apr. & 98 & 2 & 100 & \multirow{3}{*}{ Autumn $=245$} & 1 & 2 & 3 & \multirow{3}{*}{ Autumn $=23$} \\
\hline May & 61 & 25 & 86 & & 3 & 6 & 9 & \\
\hline June & 48 & 11 & 59 & & 5 & 6 & 11 & \\
\hline Total & 518 & 118 & 636 & & 106 & 34 & 140 & \\
\hline
\end{tabular}

Explanations: UBA - Ubatuba, CA - Caraguatatuba.

$1.0 \mathrm{~mm}$ (very coarse sand); $1.0-0.5 \mathrm{~mm}$ (coarse sand); $0.5-$ $0.25 \mathrm{~mm}$ (medium sand); 0.25-0.125 mm (fine sand); 0.125$0.063 \mathrm{~mm}$ (very fine sand); smaller particles were classified as silt-clay. Cumulative particle size curves were plotted on a computer using the phi scale; values corresponding to the $16^{\text {th }}, 50^{\text {th }}$, and $84^{\text {th }}$ percentiles were used to determine the mean diameter of the sediment, using the equation $M d=(\varphi 16+\varphi 50+\varphi 84) / 3$. Finally, phi was calculated using the equation $h i(\varphi)=\log _{2} d$. where $d=$ grain diameter $(\mathrm{mm})$ (Hakanson \& Jansson 1983; Tucker 1988). The organic matter content (\%) was obtained by ash-weighing: three aliquots of $10 \mathrm{~g}$ each per transect were placed in porcelain crucibles and incinerated for $3 \mathrm{~h}$ at $500^{\circ} \mathrm{C}$. The samples were then reweighed.

Sediment texture was represented graphically by plotting a triangular diagram using the three most important grain size classes, as in Magliocca \& Kutner (1965). Class A corresponds to sediments in which medium sand (MS), coarse sand (CS), very coarse sand (VCS), and gravel ( $\mathrm{G}>$ $0.25 \mathrm{~mm}$ ) account for more than $70 \%$ of the total weight. In class B, fine sand (FS), and very fine sand (VFS) make up more than $70 \%$ of the total weight of sediment samples. More than $70 \%$ of sediments in class $\mathrm{C}$ are silt and clay $(\mathrm{S}+\mathrm{C})$. These three categories were further combined to form different categories $\mathrm{PA}=(\mathrm{MS}+\mathrm{CS}+\mathrm{VCS}+\mathrm{G})>$ $70 \% ; \mathrm{PAB}=$ prevalence of $\mathrm{A}$ over $\mathrm{B}(\mathrm{FS}+\mathrm{VFS}) ; \mathrm{PAC}=$ prevalence of $\mathrm{A}$ over $\mathrm{C}(\mathrm{S}+\mathrm{C}) ; \mathrm{PB}=\mathrm{B}>70 \%$; $\mathrm{PBA}=$ prevalence of $\mathrm{B}$ over $\mathrm{A}$; $\mathrm{PBC}=$ prevalence of $\mathrm{B}$ over $\mathrm{C}$; $\mathrm{PC}=\mathrm{C}>70 \%$; $\mathrm{PCA}=$ prevalence of $\mathrm{C}$ over $\mathrm{A}$; $\mathrm{PCB}=$ prevalence of $\mathrm{C}$ over $\mathrm{B}$.

The normality and homoscedasticity of the data were tested by the Shapiro-Wilk and Levene tests, respectively. As the data did not fit a normal distribution, nonparametric tests were used. The univariate statistics were chosen instead of multivariate, because this study aimed to verify the distribution of the species in space and time without considering demographic groups, this way there were no required sample groups for the multivariate statistics execution. The abundance values were compared among transects, months and seasons using the Kruskal-Wallis test, followed by the Dunn's test. Abundance between areas and years were tested by the Mann-Whitney test. The relation-
Table 2. Absolute abundance of Callinectes danae in each area during the sampling period by depth.

\begin{tabular}{rrrr}
\hline Depth $(\mathrm{m})$ & UBA & CA & Total \\
\hline 5 & 498 & 46 & 544 \\
10 & 115 & 59 & 174 \\
15 & 21 & 22 & 43 \\
20 & 2 & 8 & 10 \\
25 & 0 & 3 & 3 \\
30 & 0 & 0 & 0 \\
35 & 0 & 2 & 2 \\
\hline Total & 636 & 140 & 776 \\
\hline
\end{tabular}

Explanations: UBA - Ubatuba, CA - Caraguatatuba.

ship between abundance of individuals and environmental factors was tested by using the Spearman correlation. The adopted significance level in all statistical analysis was $5 \%$ (Zar 2010).

\section{Results}

We collected 776 crabs, 624 in the first sampling period and 152 in the second (Table 1). We observed significant differences in the abundance of $C$. danae between sampling periods (Mann-Whitney $U=12068.50, P<$ $0.005)$. A total of 636 crabs were caught in Ubatuba and 140 in Caraguatatuba (Table 2). However, there was no significant difference in the abundance of crabs between regions (Mann-Whitney $U=13641.00 ; P>0.05$ ).

In Ubatuba, $C$. danae was more abundant in the winter, whereas in Caraguatatuba it was more abundant in the fall. In both areas (Table 1, Fig. 5), specimens were less abundant during the summer. However, neither the difference among seasons (Kruskal-Wallis, $H=4.5438, P>0.05)$, nor the differences among months (Kruskal-Wallis, $H=9.5517, P>0.05$ ) were significant. The number of $C$. danae individuals in both 

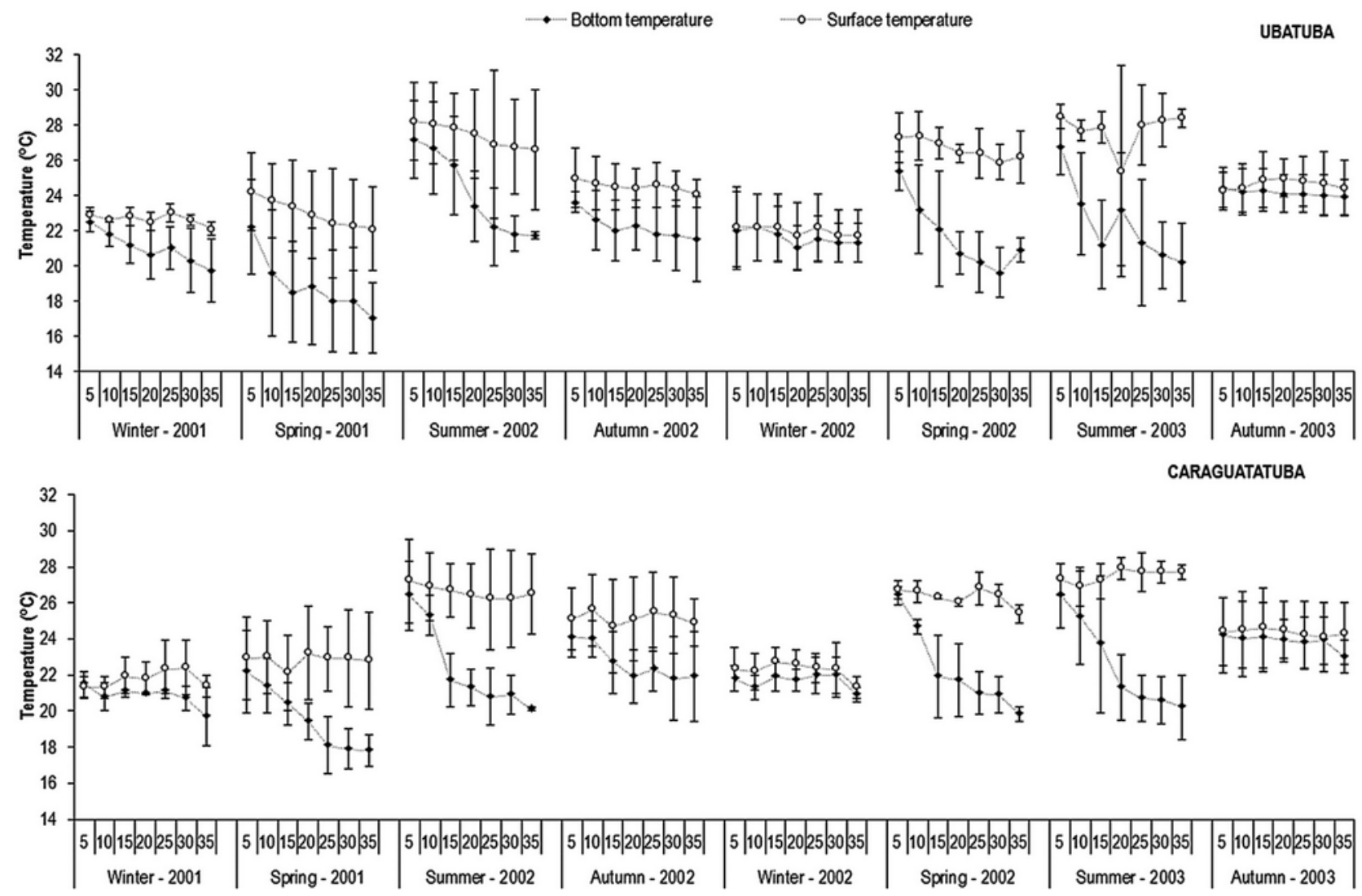

Fig. 2. Variations in the mean temperature obtained in Ubatuba and Caraguatatuba ( \pm standard deviation) by transects in each season, from July 2001 to June 2003.

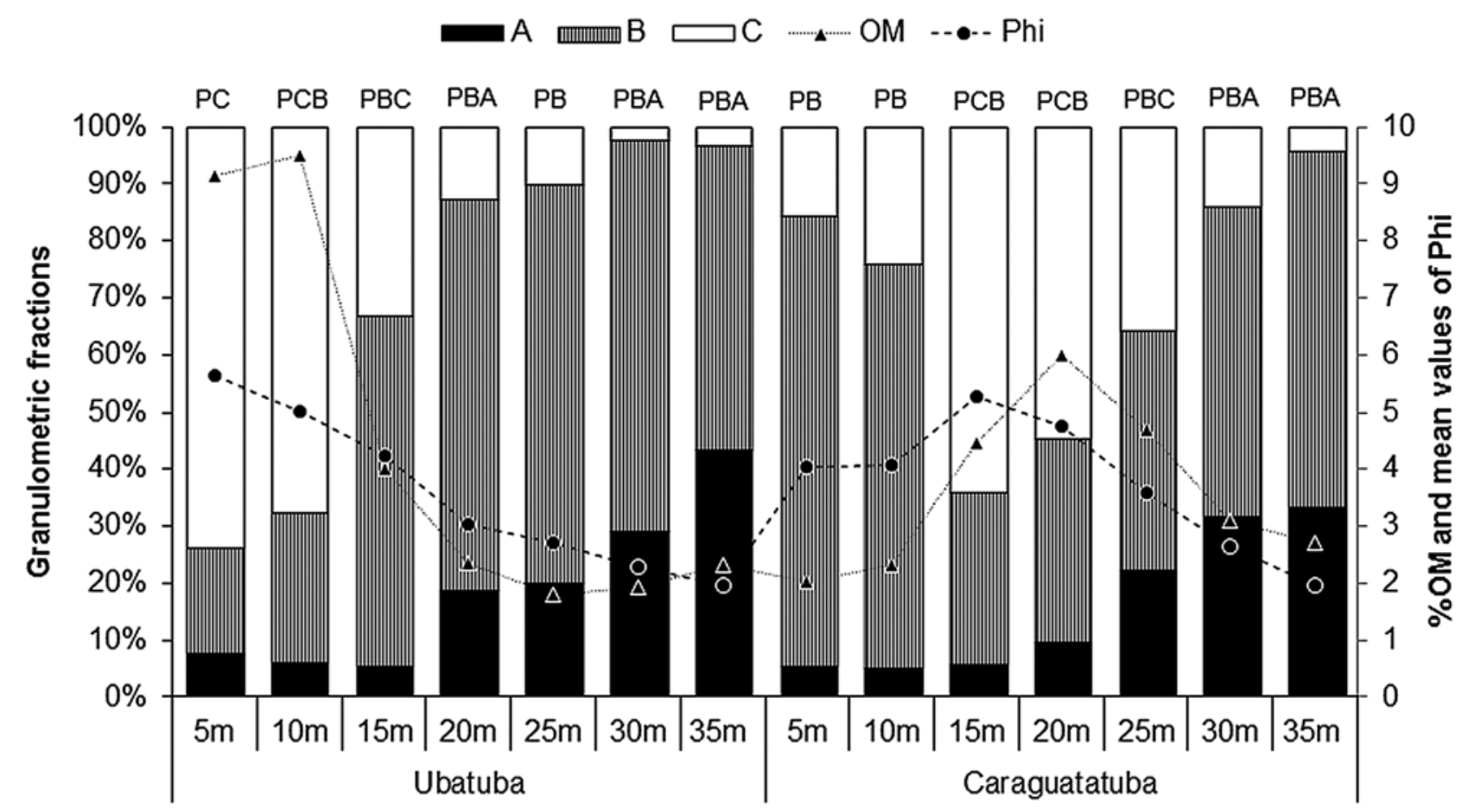

Fig. 3. Sediment results obtained in Ubatuba and Caraguatatuba: proportions of grain size classes, central tendency of sediments $(\bullet-$ Phi), and mean organic-matter content $(\boldsymbol{\Delta}-\mathrm{OM})$ for each depth. See Material and Methods for granulometric classifications (A, $\mathrm{B}$ and $\mathrm{C}$ ).

Ubatuba and Caraguatatuba was greater in the $5 \mathrm{~m}$ transects, which differed significantly from the others
(Kruskal-Wallis, $H=156.6025 ; P<0.001)$ (Figs 4,5 , Table 3). 


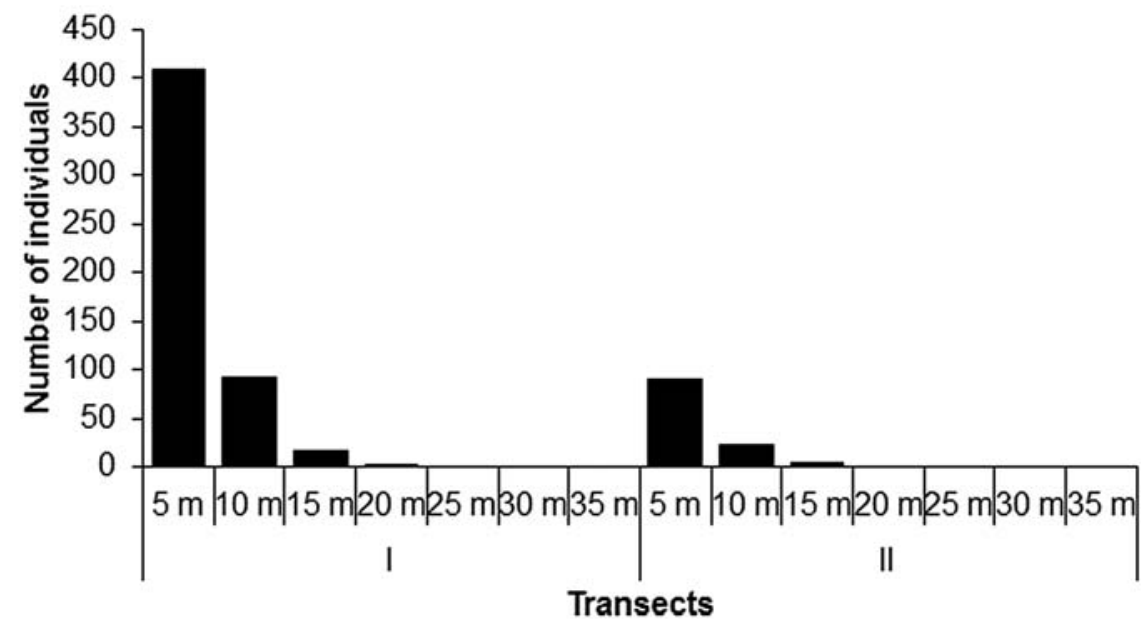

B

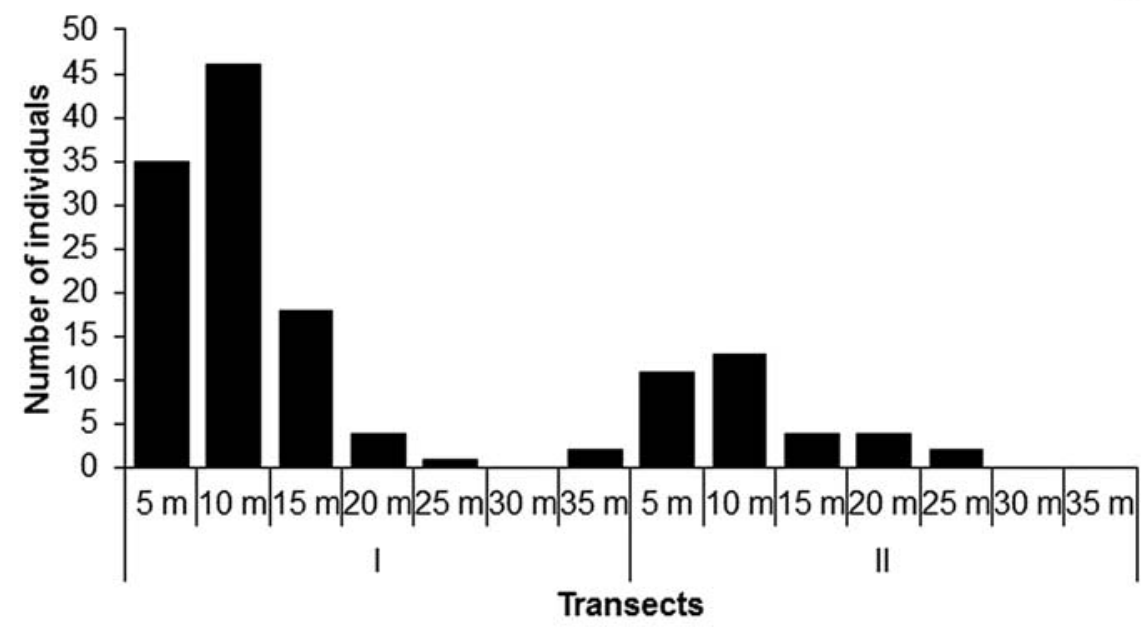

Fig. 4. Absolute abundance of Callinectes danae individuals in Ubatuba (A) and Caraguatatuba (B).

Table 3. Results Kruskal-Wallis analysis for differences in abundance of Callinectes danae between transects.

\begin{tabular}{rlcl}
\hline Transects & $n$ & Sum of ranks & $P$ \\
\hline 5 & 48 & 12688 & $*$ \\
10 & 48 & 11007.5 & \\
15 & 48 & 8502 & \\
20 & 48 & 6799 & \\
25 & 48 & 5978.5 & \\
30 & 48 & 5688 & \\
35 & 48 & 5953 & \\
\hline
\end{tabular}

Kruskal-Wallis test: $H(6, n=336)=156.6025 ; P=0.000$, $* P<0.05$.

Bottom salinity (BS) varied less in Ubatuba, ranging from 32 to $37(35.1 \pm 1.01)$. In this area, the lowest salinity values were recorded in the summer of the first and in the autumn of the second sampling periods. In Caraguatatuba, salinity ranged from 30 to 37 $(35.3 \pm 1.27)$. In this area, the values obtained for salinity were constant in the first sampling period. This value decreased in the fall of the second sampling period and reached its lowest value in the following winter. In both areas, the lowest salinity values were obtained in shallower waters $(5 \mathrm{~m}$ and $10 \mathrm{~m})$.
Table 4. Spearman correlation between environmental factors and abundance of Callinectes danae.

\begin{tabular}{lccc}
\hline Variable & $n$ & Spearman correlation & $P$ \\
\hline$S T x N$ & 336 & -0.090751 & \\
$B T \times N$ & 336 & 0.296741 & $*$ \\
$S S x N$ & 336 & -0.088648 & \\
$B S x N$ & 336 & -0.154328 & $*$ \\
Phi $x N$ & 336 & 0.435267 & $*$ \\
OM $x N$ & 336 & 0.141754 & $*$ \\
\hline
\end{tabular}

${ }^{*} P<0.05$

The mean bottom temperature (BT) in Ubatuba waters was $22^{\circ} \mathrm{C}(\mathrm{SD}=1.81)$ and the thermal amplitude was 10.2. On the other hand, in Caraguatatuba the average temperature was $21.9^{\circ} \mathrm{C}(\mathrm{SD}=1.27)$ and the thermal amplitude was 8.6. There was a difference between the maximum and minimum average values in both study areas. In Ubatuba these values were recorded in February (23.7) (summer) of the first year and in Caraguatatuba in April (25.6) (autumn) of the second year.

In both areas, the lowest temperatures were ob- 

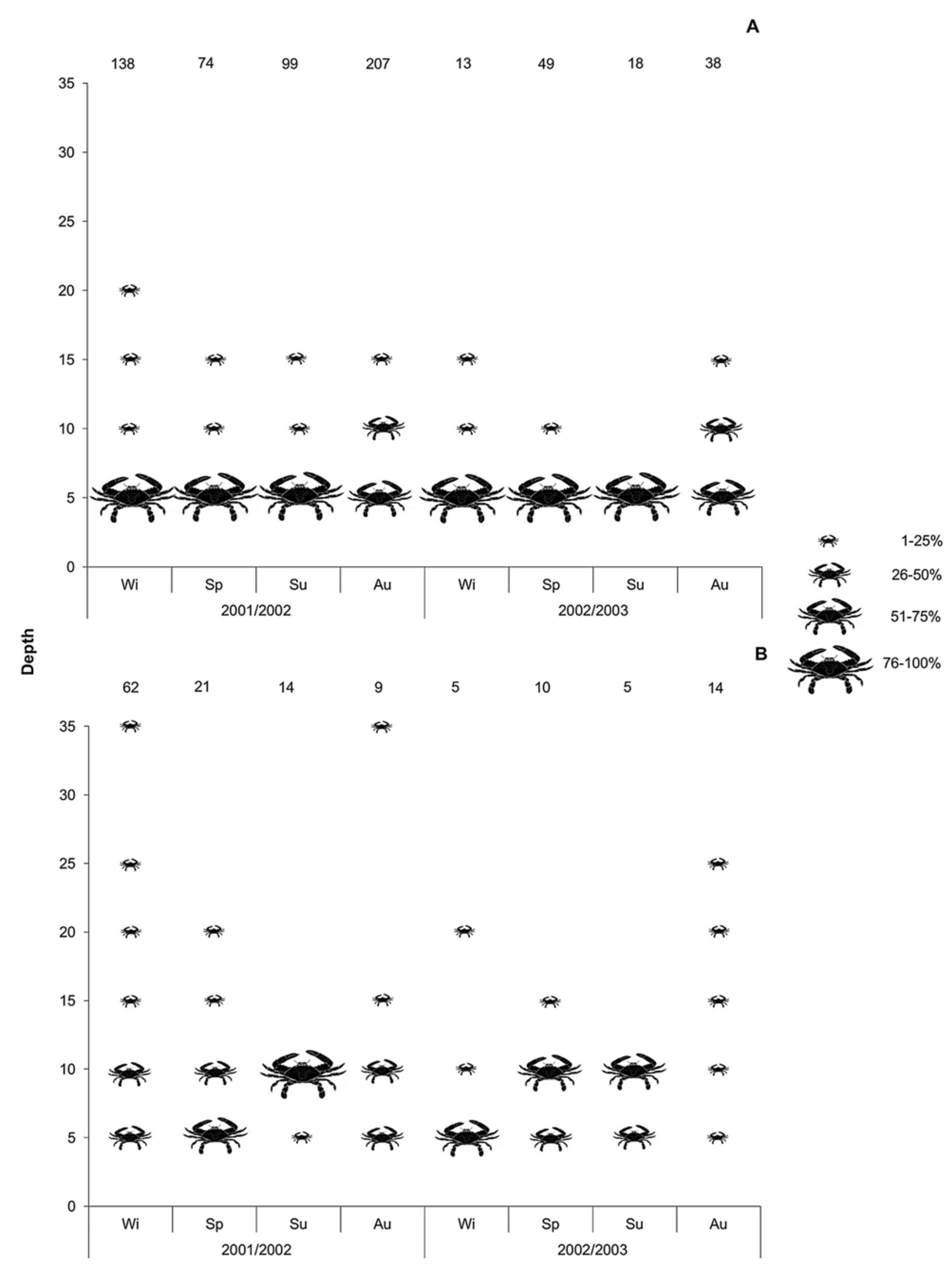

Seasons

Fig. 5. Frequency of Callinectes danae individuals by season and depth, during the investigation period. A - Ubatuba, B Caraguatatuba, Su - summer, Au - autumn, Wi - winter, Sp - spring. Numbers at the top of each graph show the total abundance of collected individuals per area/depth/season. 
tained in October $\left(17.9^{\circ} \mathrm{C}\right.$ in Ubatuba and $19^{\circ} \mathrm{C}$ in Caraguatatuba) and November $\left(16.7^{\circ} \mathrm{C}\right.$ in Ubatuba and $19^{\circ} \mathrm{C}$ in Caraguatatuba), corresponding to the spring of the first year. Temperature values were inversely proportional to increasing depth in both areas. During the spring and summer the bottom temperature decreased in both areas, and temperature variation was more pronounced in Ubatuba (Fig. 2).

Aspects of the sediment, comprising the proportions of the granulometric classes, the average values of Phi and the content of organic matter (OM) revealed different patterns of texture for the two areas. In Ubatuba the percentage of Class $\mathrm{C}$ sediments was higher in shallower $(5 \mathrm{~m}$ and $10 \mathrm{~m})$ transects, whereas deeper down $(30 \mathrm{~m}$ and $35 \mathrm{~m})$ sediment classes A and B predominated. In this same area, the values of Phi and MO were inversely proportional to depth (Fig. 3). In Caraguatatuba there were higher percentages of class $\mathrm{C}$ sediments in the intermediate $(15 \mathrm{~m}$ and $20 \mathrm{~m})$ transects, whereas the lowest values of Phi and MO were recorded in transects with greater and lesser depths, respectively. The following environmental factors were positively associated with the distribution of $C$. danae: BT, Phi and OM (Spearman correlation, $P<0.05$ ). BS was negatively associated with the distribution of the species (Spearman Correlation, $P<0.05$ ).

\section{Discussion}

According to Castro-Filho et al. (1987), the study area is strongly influenced by three water currents: South Atlantic Central Water current (SACW), with low temperature and salinity $\left(\mathrm{T}<20^{\circ} \mathrm{C} ; \mathrm{S}<36\right)$, Tropical Water current $(\mathrm{TW})$, with higher temperature and salinity $\left(\mathrm{T}>20^{\circ} \mathrm{C} ; \mathrm{S}>36\right)$, and Coastal Water current $(\mathrm{CW})$, with high temperature and low salinity $(\mathrm{T}>$ $20^{\circ} \mathrm{C} ; \mathrm{S}<36$ ). The $\mathrm{SACW}$ is one of the most important factors influencing the distribution of crustaceans in Ubatuba (Pires 1992). This water mass, besides altering salinity and temperature, also carries a significant amount of nutrients. According to Pires-Vanin \& Matsuura (1993), in Ubatuba the extent to which the SACW penetrates the bottom layer that reaches the coastal region, where the water column becomes stratified during the summer, varies seasonally. In the winter, the SACW shrinks further away from the shore, and the CW predominates. This causes the water column to be more homogeneous with respect to temperature and salinity. In the present study, the influence of the SACW was felt during the spring and summer of both years, particularly from the $15 \mathrm{~m}$ depth, since there was a stratification of the water column in these seasons, which resulted in greater amplitude of the ground and bottom temperatures. Conversely, it seems that during the autumn and winter the SACW retreated, resulting in a more homogeneous water column with increased salinity and lower temperatures. The species can be considered euryhaline (Shumway 1983) as individuals are observed in estuarine regions and other areas with higher salinity.
In the first sampling period, we observed a higher influence of the SACW in deeper waters, which may be the cause of the greater abundance of $C$. danae in the shallowest areas of sampling during this period. In both study areas the abundance was higher in transects where the granulometric fractions were smaller. Smaller fractions create more favourable conditions to the establishment of the species. In Ubatuba, abundance was greater in transects with higher Phi (finer sediment = Class C), hence with higher organic matter content. In Caraguatuba, the greatest values of abundance also occurred in shallower transects $(5,10$ and $15 \mathrm{~m})$, but class $\mathrm{B}$ sediments (fine sand and very fine) predominated in these. A few individuals were found deeper down in the water (25-35 m) in Caraguatatuba during the autumn and winter. These individuals were ovigerous females and adult females that probably migrated to deeper places where salinity is higher, to release their larvae. Larval dispersal is easier in deeper waters, due to the action of currents and winds (Hines et al. 1987; Chacur \& Negreiros-Fransozo 2001; Sforza et al. 2010). After the post-embryonic development, the larvae in a more advanced stage of development (Megalopa) return to shallow areas with lower salinity to complete their life cycles (Chacur \& Negreiros-Fransozo 2001). According Hsueh et al. (1993), the prevalence $C$. danae in estuarine areas (lower salinity) may be associated with the capacity of Callinectes Stimpson, 1870 species to osmoregulate. Another possibility may also be the need to shelter from predators, and food availability, particularly for juveniles (Lipcius \& Van Engel 1990).

In this study we found that $C$. danae is most abundant in sites where sediment grain is finer, particularly silt and clay, which may be due to the larger amount of organic matter available in this type of sediment (Melo 1996; Teixeira \& Sá 1998; Nevis et al. 2009). The preference for regions with thinner sediment may be associated with the need to search for food, because when a larger amount of organic matter is available there is an increase in the number of organisms that feed on it, including C. danae (Mantelatto 2000). Furthermore, the need to select sediments that facilitate burying may contribute further for the preference that individuals of C. danae show for these fine sediments. This burying behavior was also observed in other species of the same genus: Callinectes ornate Ordway, 1863 and Callinectes sapidus Ratbun, 1986), indicating that his behaviour is typical (Bellwood 2002).

The environmental factors considered to be more important in the distribution of benthic crustaceans are, in general, depth, salinity, and temperature and sediment texture. In this study, the importance of these factors on the abundance and spatial distribution patterns of $C$. danae have been corroborated.

We conclude that the joint influence of all environmental factors evaluated, but not any of them in isolation, modulates the distribution of $C$. danae. The influence of these factors on the distribution patterns of the species is evident when we observe the behaviour of crabs that have a limited distribution, and are restricted 
to places which have characteristics more favourable to their survival, besides we recommend distribution studies that consider demographic group of the species, thus will be possible the execution of multivariate statistics. The results presented here support the distribution pattern observed in other studies, and provided basic information for future studies addressing the structure and biology of $C$. danae.

\section{Acknowledgements}

We are grateful to Fundação de Amparo à Pesquisa do Estado de São Paulo - FAPESP for providing financial support (\#94/4878-8, \#97/12108-6, \#97/12106-3, \#97/12107$0, \# 98 / 3134-6)$. We are also thankful to the NEBECC coworkers for their help during fieldwork.

\section{References}

Aschan M. 1990. Changes in softbottom macrofauna communities along environmental gradients. Ann. Zool. Fenn. 27: 329-336.

Atrill M.J., Power M. \& Thomas R.M. 1999. Modeling estuarine Crustacea population fluctuations in response to physicchemical trends. Marine Ecology Progress Series 178: 89-99.

Baptista-Metri C., Pinheiro M.A.A., Blankensteyn A. \& Borzone C.A. 2005. Biologia populacional e reprodutiva de Callinectes danae Smith (Crustacea, Portunidae), no Balneário Shangri-lá, Pontal do Paraná, Paraná, Brasil. Rev. Bras. Zool. 22 (2): 446-453. DOI: http://dx.doi.org/10.1590/S010181752005000200022

Barreto A.V., Matos L., Batista-Leite A. \& Aguiar M.C.A. 2006. Maturidade sexual das fęmeas de Callinectes danae (Crustacea, Decapoda, Portunidae) nos estuários dos rios Botafogo e Carrapicho, Itamaracá, PE, Brasil. Iheringia, Ser. Zool. 96 (2): 141-146

Bellwood O. 2002. The occurrence, mechanics and significance of burying behavior in crabs (Crustacea: Brachyura). J. Nat. Hist. 36 (10): 1223-1238. DOI: 10.1080/00222930110048891

Bertini G. \& Fransozo A. 2004. Bathymetric distribution of brachyuran crab (Crustacea, Decapoda) communities on coastal soft bottoms off southeastern Brazil. Mar. Ecol. Progr. Ser. 279: 193-200. DOI: $10.3354 /$ meps 279193

Bertini G., Fransozo A. \& Costa R.C. 2001. Ecological distribution of three species of Persephona (Brachyura: Leucosiidae) in the Ubatuba region, São Paulo, Brazil. Nauplius 9 (1): $31-42$.

Branco J.O. 1996. Ciclo e ritmo alimentar de Callinectes danae Smith, 1869 (Decapoda, Portunidae) na Lagoa da Conceição, Florianópolis, SC. Arq. Biol. Tecnol., Curitiba 39 (4): 987998.

Branco J.O. \& Masunari S. 1992. Crescimento de Callinectes danae Smith (Decapoda, Portunidae) da Lagoa da Conceição, Florianópolis, Santa Catarina, Brazil. Rev. Bras. Zool. 9 (1/2): 53-66. DOI: http://dx.doi.org/10.1590/S0101-81751 992000100008

Branco J.O. \& Verani J.R. 1997. Dinâmica da alimentação natural de Callinectes danae Smith (Decapoda, Portunidae) na Lagoa da Conceição, Florianópolis, Santa Catarina, Brasil. Rev. Bras. Zool. 14 (4): 1003-1018.

Buchanan B.A. \& Stoner A.W. 1988. Distributional Patterns of blue crabs (Callinectes sp.) in a Tropical Estuarine Lagoon. Estuaries 11 (4): 231-239. DOI: 10.2307/1352009

Carvalho F.L., Carvalho E.A.S. \& Couto E.C.G. 2010. Comparative analysis of the distribution and morphological sexual maturity of Persephona lichtensteinii e P. punctata (Brachyura, Leucosiidae) in Ilhéus, BA, Brazil. Nauplius 18 (2): 109-115.

Carvalho F.L. \& Couto E.C.G. 2010. Environmental variables influencing the Callinectes (Crustacea: Brachyura: Portunidae) species distribution in a tropical estuary - Cachoeira River
(Bahia, Brazil). J. Mar. Biol. Ass. U. K. 91 (4): 793-800. DOI: http://dx.doi.org/10.1017/S0025315410001700

Castro-Filho B.M., Miranda L.B. \& Miyao S.Y. 1987. Condiçőes hidrográficas na plataforma continental ao largo de Ubatuba: Variaçőes sazonais e em média escala. Bol. Inst. Oceanogr. 35 (2): 135-151. DOI: http://dx.doi.org/10.1590/S037355241987000200004

Chacur M.M. \& Negreiros-Fransozo M.L. 2001. Spatial and seasonal distributions of Callinectes danae (Decapoda, Portunidae) in Ubatuba bay, São Paulo, Brazil. J. Crustac. Biol. 21 (2): 414-425. DOI: http://dx.doi.org/10.1651/02780372(2001)021[0414:SASDOC]2.0.CO;2

Costa T.M. \& Negreiros-Fransozo M.L. 1998. The reproductive cycle of Callinectes danae Smith, 1869 (Decapoda, Portunidae) in the Ubatuba region, Brazil. Crustaceana 71 (6): 615-627. DOI: 10.1163/156854098X00617

Fantucci M.Z., Biagi R., Meireles A.L. \& Mantelatto F.L.M. 2009. Influence of biological and environmental factors on the spatial and temporal distribution of the hermit crab Isocheles sawayai Forest \& Saint-Laurent, 1968 (Anomura, Diogenidae). Nauplius 17 (1): 37-47.

Fransozo A., Bertini G., Braga A.A. \& Negreiros-Fransozo M.L. 2007. Ecological aspects of hermit crabs (Crustacea, Anomura, Paguroidea) off the northern coast of São Paulo State, Brazil. Aquat. Ecol. 42 (3): 437-448. DOI: 10.1007/ s10452-007-9103-5

Hakanson L. \& Jansson M. 1983. Principles of Lake Sedimentology. Springer-Verlag, Germany, 315 pp. ISBN-10: 1930665547, ISBN-13: 978-1930665545

Hines A.H., Lipicius R.N. \& Haddon A.M. 1987. Population dynamics and habitat partitioning by size, sex, and molt stage of blue crabs Callinectes sapidus in a subestuary of central Chesapeake Bay. Mar. Ecol. Progr. Ser. 36: 55-64.

Hiroki K.A.N., Fransozo A., Costa R.C., Castilho A.L., Shimizu R.M., Almeida A.C. \& Furlan M. 2011. Bathymetric distribution of the shrimp Rimapenaeus constrictus (Stimpson, 1874) (Decapoda, Penaeidae) in two locations off the southeastern Brazilian coast. Mar. Biol. Res. 7 (2): 176-185. DOI: 10.1080/17451000.2010.489614

Hsueh P.W., McClintock J.B. \& Hopkins T.S. 1993. Population dynamics and life history characteristics of the blue crabs Callinectes similis and C. sapidus in Bay environments of the northern Gulf of Mexico. Mar. Ecol. 14 (3): 239-257. DOI: 10.1111/j.1439-0485.1993.tb00482.x

Keunecke K.A., D'Incao F., Moreira F.N., Silva D.R. \& Verani J.R. 2008. Idade e crescimento de Callinectes danae e C. ornatus (Crustacea, Decapoda) na Baía de Guanabara, Rio de Janeiro, Brasil. Iheringia, Ser. Zool. 98 (2): 231-235. DOI: http://dx.doi.org/10.1590/S0073-47212008000200011.

Lipicus R.N. \& Van Engel W.A. 1990. Blue crab population dynamics in Chesapeake Bay: Variation in abundance (York River, 1972-1988) and stock-recruit functions. B. Mar. Sci. 46 (1): 180-194

Magliocca A. \& Kutner A.S. 1965. Sedimentos de fundo da Enseada do Flamengo, Ubatuba, SP. Contrib. Avulsas Inst. Oceanogr. 198: 1-15.

Mantelatto F.L.M. 2000. Allocation of the portunid crab Callinectes ornatus (Decapoda: Brachyura) in the Ubatuba Bay, northern coast of São Paulo State, Brazil, pp. 431-443. In: von Vaupel Klein C.J. (ed.), The Biodiversity Crisis and Crustacea, Proceedings of the Fourth International Crustacean Congress Amsterdam, Netherlands, 2.

Mantelatto F.L.M., Fransozo A. \& Negreiros-Fransozo M.L. 1995. Distribuição do caranguejo Hepatus pudibundus (Herbst, 1785) (Crustacea, Decapoda, Brachyura) na Enseada da Fortaleza, Ubatuba, SP, Brasil. Bol. Inst. Oceanogr. São Paulo 43 (1): 51-61. DOI: http://dx.doi.org/10.1590/S037355241995000100005

Martínez G., Scarabino F. \& Delgado E. 2009. New records of the brachyuran crabs Hepatus pudibundus (Aethridae) and Persephona mediterranea (Leucosiidae) in their southernmost Western Atlantic distribution. Pan Am. J. Aquat. Sci. 4 (3): 279-282. 
Medeiros M.F.S.T. \& Oshiro L.M.Y. 1990. Aspectos reprodutivos de Callinectes danae Smith, 1869 (Crustacea, Decapoda, Portunidae), na baía de Sepetiba-RJ. In: II Simpósio de ecossistemas da costa sul e sudeste brasileira. Estrutura, função e manejo, 6 a 11 de abril de 1990, Aguas de Lindóia. Publ. ACIESP 4 (71): 150-159.

Melo G.A.S. 1996. Manual de Identificação dos Brachyura (Caranguejos e Siris) do Litoral Brasileiro. Plęiade/FAPESP, São Paulo, 604 pp.

Nevis A.B., Martinelli J.M., Carvalho A.S.S. \& Nahum V.J.I. 2009. Abundance and spatial-temporal distribution of the Family Portunidae (Crustacea, Decapoda) in the Curuçá Estuary on the northern coast of Brazil. Braz. J. Aquat. Sci. Techn. 13 (1): 71-79. DOI: http://dx.doi.org/10.14210/ bjast.v13n1.p71-79

Pereira M.J., Branco J.O., Christoffersen M.L., Junior F.F., Fracasso H.A.A. \& Pinheiro T.C. 2009. Population biology of Callinectes danae and Callinectes sapidus (Crustacea: Brachyura: Portunidae) in the south-western Atlantic. J. Mar. Biol. Assoc. UK 89 (7): 1341-1351. DOI: http://dx.doi.org/10.1017/S0025315409000605

Pinheiro M.A.A., Fransozo A. \& Negreiros-Fransozo M.L. 1996. Distribution patterns of Arenaeus cribarius (Lamarck, 1818) (Crustacea, Portunidae) in Fortaleza Bay, Ubatuba (SP), Brazil. Rev. Bras. Biol. 56 (4): 705-716.

Pires A.M.S. 1992. Structure and dynamics of benthic megafauna on the continental shelf offshore of Ubatuba, southeastern Brazil. Mar. Ecol. Prog. Ser. 86: 63-76.

Pires-Vanin A.M.S. \& Matsuura Y. 1993. Estrutura e função do ecossistema de plataforma continental da região de Ubatuba, Estado de São Paulo: uma Introdução. Publção Esp. Inst. Oceanogr., S. Paulo 10: 1-8.
Pita J.B., Rodrigues E.S., Graça-Lopes R. \& Coelho J.A.P. 1985. Observações bioecológicas sobre o siri Callinectes danae Smith 1869 (Crustacea, Portunidae), no Complexo BaíaEstuário de Santos, São Paulo, Brasil. Bol. Inst. Pesca 12 (4): 35-43.

Santos S., Negreiros-Fransozo M.L. \& Fransozo A. 1994. The distribution of the swimming crab Portunus spinimanus Latreille, 1819 (Crustacea, Brachyura, Portunidae) in Fortaleza Bay, Ubatuba, SP, Brazil. Atlântica 16 (1): 125-141.

Sforza R., Nalesso R.C. \& Joyeux J.C. 2010. Distribution and population structure of Callinectes danae (Decapoda: Portunidae) in a tropical Brazilian estuary. J. Crustac. Biol. 30 (4): 597-606. DOI: http://dx.doi.org/10.1651/09-3223.1

Shumway S.E. 1983. Oxygen consumption and salinity tolerance in four Brazilian crabs. Crustaceana 44 (1): 76-82.

Teixeira R.L. \& Sá H.S. 1998. Abundância de macrocrustáceos decápodas nas áreas rasas do complexo lagunar Mundaú/ Manguaba, AL. Rev. Bras. Biol. 58 (3): 393-404. DOI: http://dx.doi.org/10.1590/S0034-71081998000300005

Tucker M. 1988. Techniques in Sedimentology. Blackwell Scientific Publications, Oxford, London, Edinburgh, Boston, Palo Alto, Melbourne, 394 pp. ISBN: 0632013613

Vernberg F.J. \& Vernberg W.B. 1970. Lethal limits and the zoogeography of the faunal assemblages of coastal Carolina waters. Mar. Biol. 6 (1): 26-32. DOI: 10. 1007/BF00352604

Zar J.H. 2010. Biostatistical Analysis. $5^{\text {th }}$ ed. Prentice-Hall, Upper. Saddle. River, New Jersey, 960 pp. ISBN-13: 9780321656865

Received November 21, 2013 Accepted September 16, 2014 